\title{
Multilingualism and Language Maintenance in the East Timorese Diaspora in Portugal ${ }^{1}$
}

\section{Francesco Goglia \& Susana Afonso}

University of Exeter

\begin{abstract}
The East Timorese linguistic repertoire is complex. It comprises Tetum and Portuguese (now both official languages in East Timor), Bahasa Indonesia and other local national languages. Moreover, different generations have different degrees of knowledge and use of these languages due to historical changes and resulting language policies in East Timor. In this article, we analyze multilingualism in the East Timorese community in Portugal using sociolinguistic questionnaires on language use, choice and attitudes. The result of our analysis shows that the East Timorese multilingual repertoire is re-shaped in the immigrant context in the following way: Tetum is the only East Timorese national language which is maintained and functions as an East Timorese identity marker. Informants have a positive attitude towards Portuguese, clearly identifying it as a High language. Furthermore, Bahasa Indonesia is still maintained to a certain degree in some domains.
\end{abstract}

Keywords: Multilingualism in the immigration context; language attitudes; language choice; language shift and maintenance; language contact; East Timor.

\section{Introduction}

The independence of East Timor in 2002 marked a change in the country's linguistic ecology. The newly independent country established Portuguese and Tetum as official languages, while Bahasa Indonesia and English were defined as working languages. East Timor joined the CPLP - Comunidade dos Países de Língua Portuguesa (community of Portuguese language countries) and closer cooperation began between East Timor and Portugal so as to support 
the development of Portuguese in the territory, namely by providing training in Portuguese for teachers.

The introduction of Portuguese was not met with enthusiasm, especially by young East Timorese, who had been educated in Bahasa Indonesia and felt that in this way they were being excluded from the project of nationbuilding. Fears that the official policy would divide even more the rural and urban, educated and uneducated population grew. The relationship between the communities in East Timor and their languages consequently underwent gradual change, in particular in relation to the value associated with them. Ten years on from independence, this changing relationship can also be seen in the new diaspora in Portugal - a more mobile diaspora, which has access to social media and is in contact with other East Timorese diasporas in the world.

In this article we present some results of a British Academy research project "Patterns of multilingualism among different generations of the East Timorese diasporic community in Porto (Portugal)." We characterize qualitatively the East Timorese diaspora in Portugal, with regards to language choice and language attitudes in view of the complex linguistic situation, and to shed light on possible patterns of language maintenance and shift.

The paper is organised as follows: we begin by describing the linguistic situation in East Timor and provide an overview of East Timorese immigration to Portugal, so as to set out the context in which the study was conducted and the importance of this case study in the research on language maintenance and shift in immigrant communities. We go on to describe the methodology used in the study and present the results of our project based on questionnaires. Finally, we conclude the article with reflections on language maintenance.

\section{The languages of East Timor and a changing language policy}

The linguistic situation in East Timor is very complex; in addition to several local languages, the official languages until independence in 2002 were exogenous ones - Portuguese and Bahasa Indonesia - imposed at different stages in history: when East Timor was under Portuguese colonial rule and, after 1975, when Indonesia proclaimed the territory as one of its provinces. As an independent country, East Timor reintroduced Portuguese as an official language, 
together with Tetum, one of the local languages and a widely used lingua franca. Bahasa Indonesia and yet another exogenous language - English - were defined as working languages.

In East Timor there are 19 local languages from two language groups: Austronesian and non-Austronesian Papuan (Lewis). Table 1 shows the local languages (excluding pidgins and creoles) and the estimated number of speakers, based on the 2004 East Timor National Census (DNE 80).

Table 1 East Timorese National Languages and Estimated Number of Speakers ${ }^{2}$

\begin{tabular}{lll}
\hline Language Group & Languages & No. of native speakers \\
\hline Austronesian & Baikeno & 45,705 \\
\hline Galoli & 12,240 \\
\hline Habun & 1586 \\
\hline Kairú & 14,201 \\
\hline Kemak & 13,540 \\
\hline Makuv'a & 51,057 \\
\hline Mambae & 100 \\
\hline Naueti & 131,472 \\
\hline Tetum & 11,321 \\
\hline Tetum-Dili & 45,944 \\
\hline Tokodede & 133,102 \\
\hline Waima'a & 31,814 \\
\hline Adabe & 14,506 \\
\hline Bunak & 5,576 \\
\hline Fataluku & 50,000 \\
\hline Makasae & 30,000 \\
\hline Non-Austronesian & 70,000 \\
\hline & & \\
\hline
\end{tabular}

Table 1 shows that Tetum (including Tetum-Dili ${ }^{3}$ ) and Mambae have the highest number of speakers. However only Tetum developed as a written language, 
albeit incipiently, in the 1960s, and in 2002 became co-official language with Portuguese. All the other languages are only used orally and none of them is standardised. Tetum is spoken in more than one area across East Timor and has functioned as a lingua franca in the territory (Hajek, "Language Planning" 401) used by approximately $60-80 \%$ of the population (Hajek, "Language Maintenance" 185).

The introduction of Portuguese to the territory dates back to the 1500s when East Timor became part of the Portuguese overseas colonial Empire, a situation that lasted until 1975. However, it was not until the 1950s that the Portuguese colonial enterprise took a real interest in the territory from a cultural and educational viewpoint, with a more systematic education programme, in order to enforce rapid assimilation and to address concerns of a possible uprising. Portuguese colonial policy after 1955 meant that, theoretically, all colonies had the same status as any region in Portugal - they were renamed "overseas provinces" so as to convey the idea of a unified, multicultural empire (Vale de Almeida 91-92). In practice, this "equality" was granted to the assimilados ("the assimilated natives") who embraced Christian values, had a command of the Portuguese language, acquired through education, and enjoyed various social privileges. The assimilados represented a minority of the population: $0.25 \%$ of the pre-1975 East Timorese population (Weatherbee 684). East Timor was the most remote overseas Portuguese territory. The spread of the Portuguese language was limited and levels of literacy during Portuguese colonial rule were very low. Furthermore, the Portuguese used Tetum as a lingua franca, and as a result, the introduction of Portuguese did not disrupt the stable multilingualism in the territory (Hajek, "Language Maintenance" 185).

Between 1976 and 1999, under the Indonesian regime, Portuguese was officially eliminated from the territory, Tetum discouraged (although tolerated in Catholic services and in some religious schools) and other national languages ignored. Bahasa Indonesia was established as the official language. However, Portuguese and Tetum survived as part of the resistance against Indonesian rule. The first armed resistance in East Timor and members of the resistance in the diaspora, many of whom belonged to the educated elite, used Portuguese to communicate with the outside world. The cultural resistance, through the Catholic Church, also used Portuguese and, especially Tetum. Contrary to 
Portuguese colonial policy, Indonesia imposed very forcefully a programme of acculturation, which necessarily included the introduction of Bahasa Indonesia in the territory, given that Indonesianisation of the territory was seen as fundamental to national unity (Dardjowidjojo). In addition to the widespread education programme, which resulted in a rapid growth of Bahasa Indonesia speakers in East Timor in just a decade (30\% in 1980 to 60\% in 1990 (Hajek, "Language Planning" 405)), a significant number of Indonesians migrated to East Timor (Carey). As a result, the influence of Bahasa Indonesia in the East Timorese communities was far stronger than Portuguese had been, producing changes in the linguistic ecology. Bahasa Indonesia was starting to function as a lingua franca across the territory and even had a very direct and clear impact on Tetum, which, through contact, underwent accelerated grammatical simplification and borrowed heavily from Bahasa Indonesia. The local communities, and consequently the local languages, were also disrupted by massive dislocation of populations, but they nonetheless survived Indonesian rule. The fact that the population had little access to education, to information, and to media, and was not mobile, slowed down language shift towards Bahasa Indonesia.

After the referendum in 1999, which led to East Timor's independence from Indonesia, the linguistic ecology was to change yet again. The 2002 Constitution established Portuguese as official language, after 25 years of interruption, together with Tetum, and assigned the status of working languages to Bahasa Indonesia and English. ${ }^{4}$ The local languages were granted the status of national languages and Part I, Section 13 of the Constitution states that "the other national languages shall be valued and developed by the State." What the state is actually doing to develop the languages is unclear. The national languages do not seem to have a place in schools and their promotion seems to be restricted to projects (many of them outside East Timor) aiming to document the languages and create teaching materials. ${ }^{5}$ However, as Taylor-Leech (“The Language Situation" 26) points out, the national languages retain a symbolic rather than a substantive status. This language policy did not seem to take into consideration that only a very small percentage of East Timorese had any knowledge of Portuguese. Furthermore, introducing Portuguese in schools was undermined by the fact that there were insufficient human or material resources 
put in place. After the referendum, a wave of violence destroyed much of the infrastructure including $75-80 \%$ of primary and secondary schools (IEG 2). The vast majority of the teachers were educated in Bahasa Indonesia, many of them transmigrants from Indonesia, with no knowledge of Portuguese or contact with Portuguese culture. All educational materials in Tetum and Portuguese (in the latter case, completely foreign to teachers, students and parents alike) had to be created from scratch. A huge investment in improving school facilities and training teachers in Portuguese has not yet seen significant results; despite the efforts and although enrolment in primary and secondary education has increased, "a full cohort of the youth population is functionally illiterate" (IEG 35). One of the reasons given is the "lack of adequate attention to the complex language situation for effective teaching" (IEG ix).

As for the relationship between the languages, there has always been a situation of diglossia (Fishman, "Bilingualism") with asymmetrical multilingualism, imposed by the linguistic history of the country, in which Portuguese is the High language, Tetum is progressively being used in High domains, at the same time as it coexists in Low domains. The national languages are the Low languages, English and Bahasa Indonesia compete with the official languages, and Bahasa Indonesia is still widely used both as a High language and in lower domains. ${ }^{6}$ Taylor-Leech ("The Language Situation" 18, 56) argues that the diglossic situation in East Timor is unstable, due to the shifting status of the languages in society as well as the changing relationship between the languages and that there is evidence that language shift is taking place. For instance, the use of Tetum in traditionally non-Tetum areas is increasing, putting at risk other local languages (Himmelmann and Hajek 93), whose status is lower than any of the official and working languages. However, Portuguese enjoys more prestige than Tetum in formal contexts, possibly because Tetum is still undergoing expansion, and terminology in many domains is still being developed.

\section{Immigration in Portugal and East Timorese immigration}

Portugal has undergone heavy emigration waves, especially until 1975, when emigration and immigration began to balance each other. The first immigration wave from the PALOPs - Países Africanos de Língua Oficial Portuguesa 
(Portuguese-speaking African countries) took place between the 1960s and 1970s. In the second half of the 1960s Cape Verdeans immigrated to Portugal as a response to Portuguese emigration and to the colonial war, which left a gap in the labour force in the Portuguese economy (Malheiros). Cape Verdeans constitute the oldest established Lusophone community in Portugal (Rocha-Trindade 199).

It was especially after 1974 that Portugal began to play a new role as a country of immigration. Generally, immigration waves to Portugal can be divided into three distinct periods. In the first period between 1975 and 1977, in the aftermath of the collapse of the Portuguese colonial empire, the majority of the immigrants were from the PALOP, and in smaller numbers from the other colonised territories, such as East Timor. In two decades, the total number of immigrants in Portugal rose from 30,000 in 1975 to 500,000 in 2004. ${ }^{7}$ In the second period in the mid 1980s, Portugal sees an intensification of immigration, especially from Angola and Guinea-Bissau, while in the 1990s, the immigrant groups are more diversified, including Brazilians, Chinese and Indians. The late 1990s correspond to a radical shift in relation to the previous two periods; there is a boom in immigration from outside the Lusophone realm, namely from Ukraine, Russia, Moldova and Romania. In a short period of time, Eastern European immigrants became the largest ethnic group in Portugal, representing in $200720 \%$ of the immigrant population.

In this context, the East Timorese immigration is different in nature. The continuing immigration from Lusophone Africa was mainly due to economic factors, whereas East Timorese immigrated between 1975 and 1999 for humanitarian reasons. The East Timorese immigrated mainly to Portugal and Australia. It is estimated that between 1975 and 1999, 10,000 people fled to Portugal, 10,000 to Australia, and others to Macau, Mozambique, Angola, Canada, the U.S., Ireland and the United Kingdom in smaller numbers (Wise, "Nation, Transnation" 151). Before 1976, when East Timor was still part of the Portuguese colonial empire, immigration to Portugal was rare, and was reserved almost exclusively for the literate men who came to Portugal for higher education. Four different waves into Portugal are identified before 1999 (Viegas), and a fifth one after independence, based on the causes of migration, and on the features of each migration group: 
- July to October 1976: literate elite of East Timor, including civil servants and former Portuguese colonial administrators.

- 1977 to 1981/2: Immigrants of Chinese origin, economically more affluent in East Timor, not involved in political issues.

- 1982 to 1993: Reunion of East Timorese families (protocol between Australia, Portugal and Indonesia) and humanitarian cases. This is when the diaspora in Portugal became more heterogeneous, both ethnically and linguistically.

- 1993 to 1998: Asylum-seekers as a consequence of the Santa Cruz massacre. Mainly males between 18 and 30 years old, educated in Bahasa Indonesia with very little or no knowledge of Portuguese (Vale de Almeida 97). ${ }^{8}$

- 2002 to 2011: Educated East Timorese undergoing training in several areas of higher education.

Between 1980 and 1986, and 1991 and 1993, many East Timorese already in Portugal moved to Australia for economic reasons and geographic proximity to East Timor (Viegas 123) and to be reunited with their families from whom they had been separated when they fled East Timor (Fallon 71). After independence in 2002, the East Timorese diaspora in Portugal underwent some changes: many returned to East Timor, and a new type of immigration emerged. Protocols between Portuguese and East Timorese universities ensured training of East Timorese teachers in Portuguese and other subjects. This is a new form of immigration: East Timor is a free independent country, and this new diaspora is not a forced one. The new wave of East Timorese immigrants is less politicised and forms looser links with the already established diaspora in Portugal. Through the creation of associations, especially by the educated East Timorese immigrants, newcomers were helped to integrate (Viegas 119). The leader of one of the East Timorese associations, Associação Tane, in Porto, has expressed concern about the lack of interest of East Timorese in participating in cultural and political events (João Barros p.c.). A similar scenario has been described by Wise ("Nation, Transnation") in relation to the diaspora in Australia. 
Table 2 Linguistic Repertoire of the East Timorese Immigrant Groups

\begin{tabular}{|c|c|c|}
\hline Immigration waves & Characteristics of the immigration groups & Languages \\
\hline 1976 & $\begin{array}{l}\text { Literate elite of East Timor, including civil } \\
\text { servants and former Portuguese colonial } \\
\text { administrators }\end{array}$ & $\begin{array}{l}\text { Portuguese, national } \\
\text { languages and Tetum }\end{array}$ \\
\hline 1977-1981 & $\begin{array}{l}\text { East Timorese of Chinese origin, economic } \\
\text { affluent }\end{array}$ & $\begin{array}{l}\text { Hakka, Cantonese, } \\
\text { Mandarin, Portuguese, } \\
\text { Tetum and perhaps } \\
\text { national languages } \\
\text { (Hajek, "Language } \\
\text { Maintenance" 182) }\end{array}$ \\
\hline $1982-1993$ & Reunion of East Timorese families & $\begin{array}{l}\text { Different levels of com- } \\
\text { mand of Portuguese, } \\
\text { national languages } \\
\text { and Tetum, Bahasa } \\
\text { Indonesia }\end{array}$ \\
\hline 1993-1998 & $\begin{array}{l}\text { Educated male asylum-seekers ( } 18-30 \text { years } \\
\text { old) as a consequence of the Santa Cruz } \\
\text { massacre }\end{array}$ & $\begin{array}{l}\text { Very little if any Portu- } \\
\text { guese, Bahasa Indone- } \\
\text { sia, national languages } \\
\text { and Tetum }\end{array}$ \\
\hline 2002-2011 & Educated East Timorese & $\begin{array}{l}\text { Portuguese, Bahasa } \\
\text { Indonesia, English, } \\
\text { national languages, and } \\
\text { Tetum }\end{array}$ \\
\hline
\end{tabular}

Quantifying the number of East Timorese in Portugal (and elsewhere) is very difficult for the following factors: 1) many of the East Timorese that came to Portugal had Portuguese citizenship, 2) East Timorese nationals were categorised as Indonesian before independence, and 3) many are undocumented. Indeed the numbers provided by Portuguese official statistics are not reliable: approximately 153 people in total in 2010. Viegas reports that in 1998 there were approximately 1500-2000 East Timorese in Portugal (124). Even though the official figures are not realistic, statistics do show a steep increase of East Timorese immigration; 
between 2006 and 2010, the East Timorese population increased by 56.8\%, with the highest increase observed in university cities like Braga, Coimbra and Évora. This signals that a new wave of immigration, more mobile, voluntary, mainly composed of educated East Timorese, is arriving in Portugal for training purposes under the agreements between the Portuguese universities and the East Timorese government. Portugal has played a major role in the dissemination and consolidation of the Portuguese language in East Timor as well as in providing training in different areas, so that these individuals can maintain the structures of the country once the international teams have left (Bolina 192).

Linguistically speaking and taking into account the language policy in East Timor and the characteristics of the migration waves, it is possible to make certain assumptions about the linguistic characteristics of the diaspora, which are summarised in table 2 .

\section{Language maintenance and language shift in the immigration context}

Immigrant communities are the ideal locus for the study of language shift and maintenance, and the outcomes of language contact. In the literature on language shift in the immigrant context, it is often assumed that language shift takes place within three generations. The first generation uses its first languages (L1) and has the language of the host society as a foreign language. The second generation grows up bilingual speaking the L1s domestically and the language of the host country in most other domains. The third generation is likely to become monolingual in the L1 only (Coulmas 158). However, the degree of multilingualism patterns and the speed of language shift vary according to the ethnolinguistic group and attitudes towards immigrant languages in the host country. ${ }^{9}$

The study of language shift and multilingualism in immigrant communities is more recent in Europe and reflects the history of immigration which started in the northern European countries in the 1950s and only in the late 1970s in the southern European ones. While there are some studies on multilingualism and language maintenance in immigrant communities in the first group of countries, there is a lack of studies in the latter group due to the more recent immigration and to the fact that in these countries governments have 
been more involved in issues of language teaching and assimilation, rather than focusing on issues of multilingualism. ${ }^{10}$ Extra and Yagmur stress that there is a lack of empirical data both on the use/choice of languages (the sociolinguistic aspect of multilingualism) and on language patterns, language mixing, linguistic features of contact varieties in the immigration context. This bottom-up knowledge would inform stakeholders and educators involved in immigration issues.

The study of language choice and use in immigrant and diasporic communities in Portugal is also very recent (cf. Märzhäuser on Cape Verdeans in Lisbon) and the literature on the topic is scarce. In the case of the East Timorese in Portugal, the results of our study may inform both the Portuguese government (including local authorities) and East Timorese stakeholders who deal with the language planning in progress in East Timor. The majority of the immigrants in Portugal come from postcolonial contexts and share some knowledge of Portuguese. ${ }^{11}$

The East Timorese are a further interesting case among postcolonial immigrant communities in Portugal. While in Cape Verde, Mozambique and Angola, the Portuguese language is well established as a second language ${ }^{12}$, in East Timor it is a residual language becoming official again only ten years ago as part of an on-going process of language planning. Issues of language maintenance and use/choice in the immigrant context are strictly linked to what is going on in terms of language planning in East Timor and in other East Timorese diasporic communities in the world. The study of language use and choice in such communities is of paramount importance, since they can reveal the actual linguistic behaviour of speakers themselves and their attitudes, which can be compared to the expected outcomes of the new language policy.

Due to the historical events outlined above, different East Timorese age groups have lived in different language ecologies in East Timor. Our study aims to assess the extent to which the multilingual repertoire of each age group is reproduced in the immigrant context and the ways in which it is re-shaped and re-constructed in the new linguistic ecology and reflects the two brand-new identities: 1) the one of the country of origin (newly independent with a new language policy) and 2) the one of being an immigrant, whether temporarily or permanently, in the host country. 


\section{Data collection and informants}

In order to investigate language use, choice and attitudes of the East Timorese diaspora, we chose two data-collection techniques: the questionnaire and the recording of spontaneous speech. A total of 23 informants filled in the written questionnaire in the presence of the Research Assistants. The questionnaires were in Portuguese and composed of open-ended questions on language use and variation, language and identity, and language attitudes. Table 3 gives an outline of the questionnaire.

Table 3 Outline of the Questionnaire

\begin{tabular}{ll}
\hline Questions & Focus \\
\hline $1-5$ & Language repertoire, language proficiency \\
$6-7$ & Language choice with different age groups and language preference \\
$8-12$ & $\begin{array}{l}\text { Immigration to Portugal and life in the country } \\
13-16\end{array}$ \\
& $\begin{array}{l}\text { Access to media in their languages, contact with other East Timorese in Portugal } \\
\text { and in other countries }\end{array}$ \\
\hline
\end{tabular}

The second technique comprised the recording of informal conversations to obtain spontaneous linguistic data, each with two or more community members and the Research Assistants, who were also members of the community. In this paper, our discussion is based on the analysis of the questionnaires. All necessary ethical steps were taken in order to gain consent of the participants and preserve the informants' anonymity. In this study each informant is referred to with a letter, while the preceding numbers (1-3) indicate which age group they correspond to. The three age groups roughly correspond to the three major changes in language policy and planning in East Timor: age group 1 (born between 1975 and 1997), age group 2 (born between 1950 and 1975), and age group 3 (born before 1950). Nine informants belong to age group 1, 13 belong to age group 2 and 1 to age group 3 . Eighteen informants are students and 5 are professionals working in Portugal. The informants were contacted via 1) the East Timorese university student associations in Braga, Coimbra, 
and Évora, 2) Tane, an East Timorese community association in Porto, and 3) Research Assistants' personal contacts. All the informants belong to the educated elite. In fact, as it is clear from the characteristics of each immigration wave (see table 2), the diasporic community in Portugal is composed of highly educated or economically affluent individuals, who will potentially lead changes in the linguistic ecology, both in the immigration context and in East Timor. ${ }^{13}$ Speakers were able to provide multiple answers for the same question or to leave it blank. For this reason, the figures in the graphs do not always add up to the total number of informants.

\section{Language use and changing patterns in the linguistic repertoire in Portugal}

The first part of the questionnaire dealt with the linguistic repertoire of the informants in Portugal. This provided us with information on the languages and their domains of use for the analysis of language choice and maintenance in the new context. As we have seen in section 2, the linguistic repertoire of East Timorese is multiple and varies according to the age group due to several changes in language policy and planning. In the diaspora context East Timorese enrich their linguistic repertoire with the language of the host country and reshape their language-use patterns. Although Portuguese is the newly chosen co-official language in East Timor, the number of native speakers of Portuguese in East Timor is very low (DNE 80). This situation was reflected in the results of our survey.

Figure 1 illustrates the native languages of the informants. It shows that Tetum has the highest score as native language especially in age group 1 . This reflects the gradual language shift towards Tetum in East Timor at the expense of the national languages (see section 2). The figure also shows that Portuguese is the native language of eldest informant, namely 3Q. Other national languages were also indicated by the informants. Notice, however, that none of the informants have Bahasa Indonesia as their native language, which reflects their East Timorese ethnicity. 
Figure 1 Native Languages ${ }^{14}$

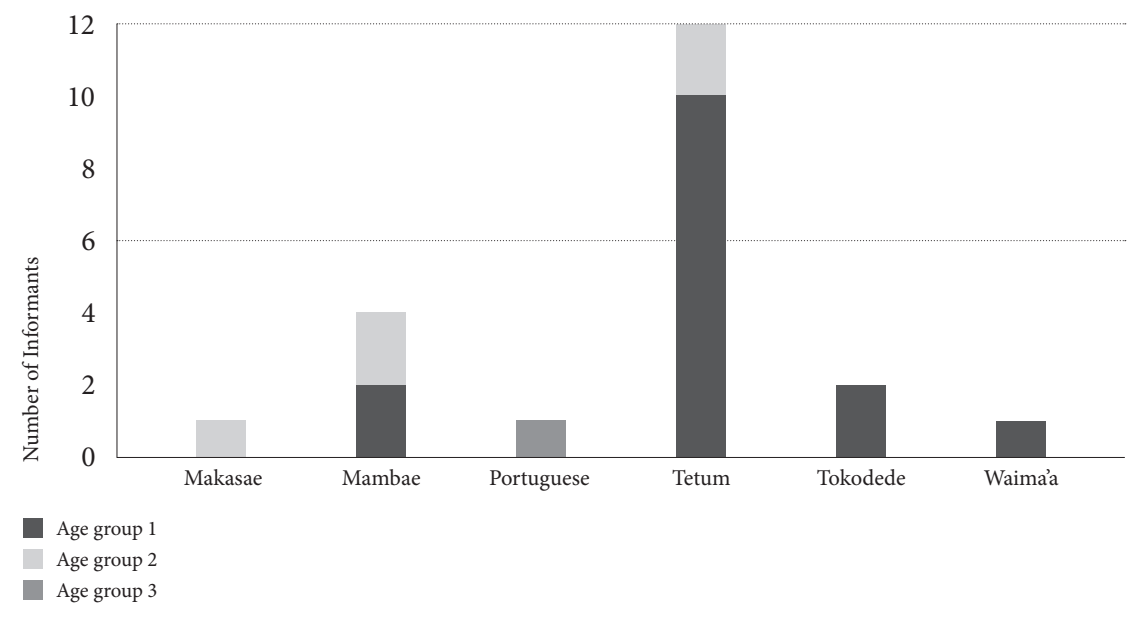

The language used in formal education reveals further insights into language shift and emphasises differences between age groups. Given the alternating language policies in East Timor, the different generations received education in different languages. Figure 2 shows the languages used in the formal education of the informants. Bahasa Indonesia scored higher in both age groups 1 and 2. This was expected since until the independence it was the sole official language. Although Portuguese and Tetum are the new co-official languages, Bahasa Indonesia is still widely used in East Timor and it is clearly still used by the two youngest groups of informants (see section 2 and table 2). Twelve informants reported that they use it to communicate with the younger generations, 8 with friends and 6 with their partners. It is also still used as a lingua franca among people who do not speak the same language (6 informants) together with Tetum. 
Figure 2 Languages Used in Formal Education

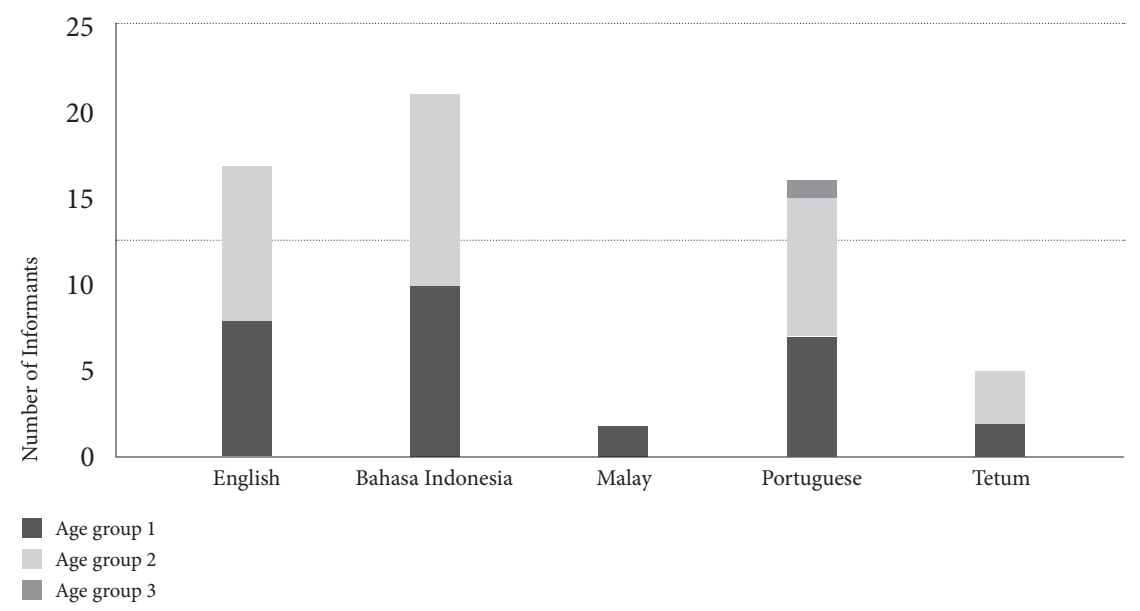

Portuguese and English follow as the languages most used in formal education and this may be due to the fact that the majority of our informants are students who need to have some knowledge of Portuguese in order to study in Portugal and may have studied English too, as in the Indonesian education system English was introduced as a way to displace Portuguese (Taylor-Leech, "The Ecology of Language"). English also gained popularity, as it was the official language of the United Nations when its observers were responsible for observing national security after the post-referendum wave of violence. Portuguese is also the language that will provide integration in the host society if any of the informants intend to continue living in Portugal in the longer term.

It is worth noting that Tetum scores very low in the question on formal education. This can be explained by the fact that it was discouraged during Indonesian rule and it is still undergoing standardisation, which will make it suitable for all levels of formal education.

The other national languages are not learned at school as they occupy the lowest level in the polyglossic linguistic situation of East Timor. Their presence in the linguistic repertoire is nevertheless acknowledged since they are mentioned as "native languages," "parents' native languages" and "languages spoken with parents and grandparents." This confirms the domestic domain of 
national languages in East Timor, but also reflects the awareness of a complex linguistic repertoire.

\subsection{Language choice with different interlocutors}

Question 6 in the questionnaire dealt with the choice of languages with different interlocutors (partners, children, friends, older generation, young generation, people who do not speak the same languages). Nineteen informants answered the question. As for the languages used with partners, Bahasa Indonesia, Tetum and Portuguese were the only languages mentioned. Tetum scores higher than Portuguese and Bahasa Indonesia, as shown in figure 3. This is due to the fact that even in East Timor Tetum is more likely to be used in the domestic domain.

Figure 3 Language Used with Partners

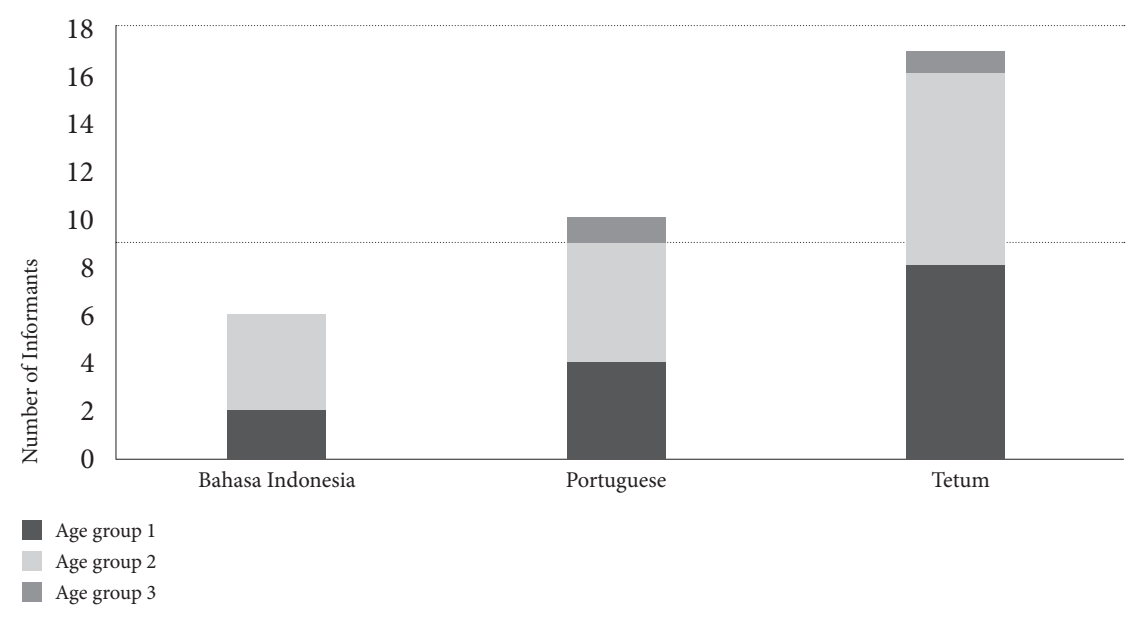

The fact that only 6 informants answered Bahasa Indonesia mirrors the mainly public use of this language in East Timor, which is not reflected in the immigration context where Portuguese is the only High language. It would appear that Bahasa Indonesia survives in the domestic domain in the immigration context where it shifts to a low language status. The national languages, on the other hand, do not survive in this domain in the immigration context and 
are replaced by Tetum and Bahasa Indonesia in lower domains, unlike in East Timor. Further evidence of this can be gathered from figure 4, which shows that only Tetum and Portuguese are passed on to children (with the exception of one speaker who answered Bahasa Indonesia). Age groups 2 and 3 seem to pass on both Portuguese and Tetum, while the youngest generation, age group 1, shows a tendency to speak Portuguese to their children, hence to assign more value to this language for the future of their children. It seems that language shift towards Portuguese and Tetum is taking place at a faster pace than in East Timor where, as Taylor-Leech ("The Ecology of Language Reform" 12) stresses, the official use of Tetum and Portuguese and the resulting language shift in favour of these languages is actually slowed down by the extensive use of English and Bahasa Indonesia.

Figure 4 Languages Used with Children

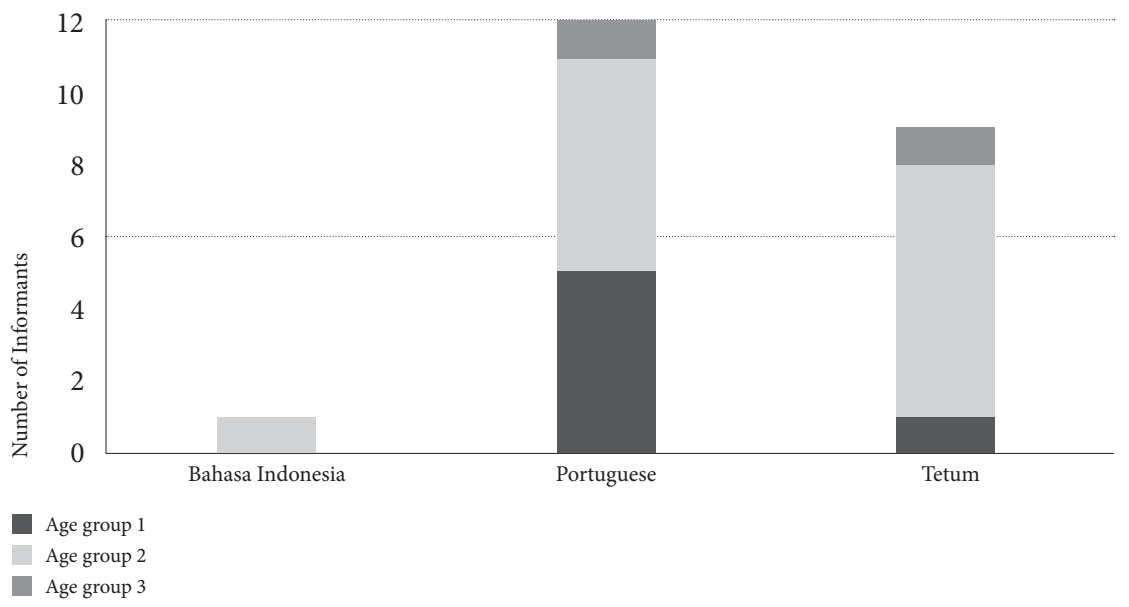

As figure 4 shows, 9 informants say that they speak Tetum with their children, 7 of them belong to age group 2 . This result, together with the above-mentioned majority of speakers who use Tetum with partners and friends, shows loyalty towards Tetum and evidence of language maintenance in the immigrant context. This may be due to an intention to go back to East Timor one day or to a newly acquired pride of being East Timorese even in the diaspora. 
Our survey reveals that in the re-shaped linguistic repertoire in the immigration context the national languages are neither passed on to children nor used to communicate with partners. Only a few informants tick any national languages under "communication with friends" and "old generation." This is clearly revealing language shift in favour of the dominant languages in the repertoire at the expense of the national languages. This process is already documented in East Timor (Taylor-Leech, "The Ecology of Language Planning"), and of course emphasized in the immigration context in which national languages are even lower in the polyglossic hierarchy. It is also very likely that the use of these languages both in East Timor and in Portugal takes place only in a mixed mode. This is often regarded in the literature on language maintenance and shift as a sign of incipient language shift. The informants tend to maintain some kind of multilingualism in the new context, but their multiple linguistic repertoire only includes the High languages of their original linguistic repertoire. This is in line with Clyne and Kipp (38), whose research found that people coming from a country with high levels of multilingualism tend to maintain this level more than people coming from monolingual countries.

Although code-switching is beyond the scope of this article, it is worth mentioning that while answering the question as to which language is used with the younger generation, speaker $2 \mathrm{~S}^{15}$ mentioned Gado Gado ${ }^{16}$, which he defined as being "a mixture of Tetum, Portuguese, English and Bahasa Indonesia." Bahasa Gado Gado or "salad language" is used in Indonesia to refer to the frequent use of code-switching and mixing in everyday conversation.

Our survey also reveals that Portuguese is actually passed on to children although the informants (with the exception of $3 \mathrm{Q}$ ) are not native speakers. It is very interesting to note that no informants mentioned differences between European Portuguese and the variety spoken in East Timor. Indeed the variety used in administration and education is European Portuguese, but the local spoken variety (whether as a first or second language) is very likely to be influenced by the substrate languages. ${ }^{17}$ In the new immigrant context, children are exposed to European Portuguese, but also to the East Timorese variety spoken by their parents. This situation is similar to those in other postcolonial countries in which the linguistic repertoire of the immigrant group also includes a 
variety of the language of the host country. However, the community does not seem to be willing to flag a different variety of Portuguese in their repertoire. ${ }^{18}$

\subsection{Language preference}

Figure 5 shows which language the informants indicated as their "favourite language." Tetum scored very highly also in the question on the "favourite language." In support of this the main reasons given by the informants are Tetum being their native language (cf. figure 1) and official national language in East Timor, and because it is a local lingua franca. Speaker $2 \mathrm{G}$ wrote "because when I speak Tetum, it is a sign that I am East Timorese." The role of Tetum as a marker of national identity was already boosted during the war of independence by the resistance and the church leaders (Taylor-Leech, "The Ecology of Language Reform"). The emphasis on Tetum as "favourite" and national language may also be triggered by the immigration context in a country in which Portuguese, the other official language of East Timor, is also the language of the host country, and less useful for the creation of an individual identity. Ten informants say that Portuguese is their "favourite language." Reasons given by the informants include:

- "It is the official language of East Timor" (2D),

- "It is the most beautiful language in the world" $(1 \mathrm{~N})$,

- "It is the language of culture" (3Q)

- "It's the most difficult one at the moment and I would like to deepen my knowledge of it" (1X).

The above statements reveal a positive attitude towards Portuguese. Portuguese, contrary to Tetum, is clearly perceived as a High language, worth studying and knowing both in the immigrant context and potentially in East Timor, rather than as a marker of identity. Only one speaker mentioned Bahasa Indonesia as a "favourite language," justifying his choice by the fact that his "degree is in Indonesian language" (1C). Three informants mention English as a "favourite language." English holds a very high status both in East Timor, where it is a working language together with Bahasa Indonesia, and in the immigrant context in Portugal, where it is a useful foreign language. 
Figure 5 Favourite Language per Age Group

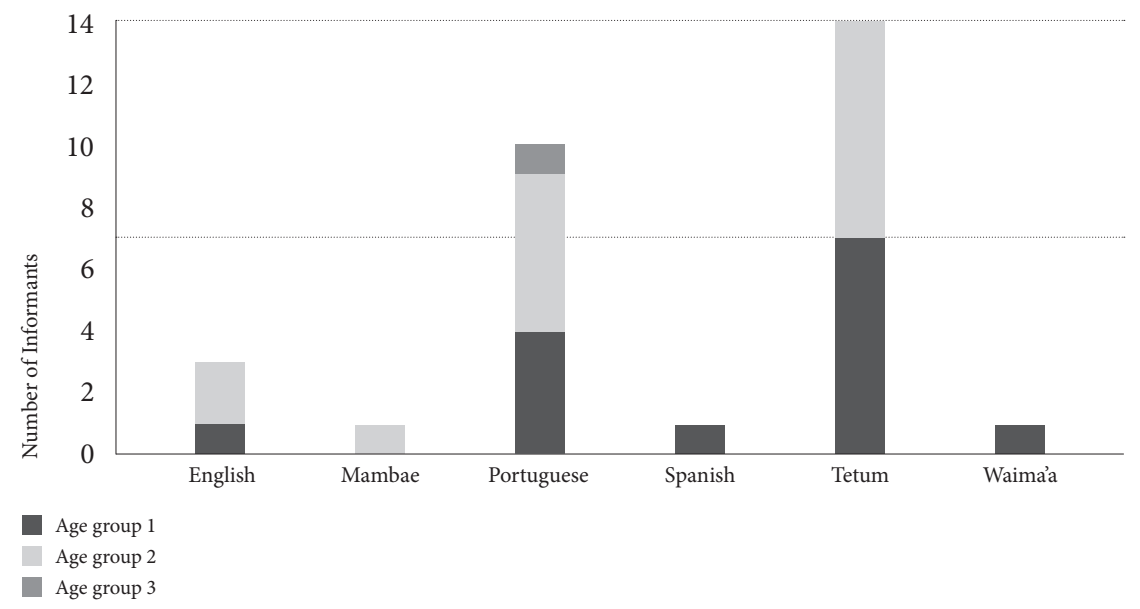

Of the national languages, which are also the informants' native language (see figure 1), only Mambae - a widely spoken language - and Waima'a were mentioned as their favourite language, highlighting a residual attachment to the national languages.

\subsection{Social networks and media}

The majority of informants indicate Portuguese and East Timorese as the nationalities of their friends as shown in figure 6. Our informants maintain contact both with local people, for example, students at the university, and other East Timorese. ${ }^{19}$ This favours language maintenance in the immigrant context and shows strength in a small community which otherwise could be easily assimilated, linguistically and culturally. Clyne and Kipp (38) point out that a high level of education "brings immigrants closer to the cultural life of the dominant group, multiplying possible points of contact and thus promoting language shift." Our study shows that language shift in favour of Portuguese and Tetum is well underway. Indeed, even if the majority of our informants are likely to return to East Timor, their level of education and quest for a better future are contributing factors to language shift.

Figure 6 shows that some informants also indicate as their friends' nationalities Brazilian, Mozambican and Cape Verdean, i.e. the main Portuguese-speaking 
immigrant groups in Portugal. This is an important factor preventing language maintenance since they will not be able to use any of the East Timorese languages with these immigrant groups, other than Portuguese. However, the linguistic features of the Portuguese variety used among immigrants coming from different Portuguese-speaking countries are likely to be influenced by all the varieties spoken by these groups.

Tetum and the other national languages of East Timor do not have any official place in the new linguistic ecology since Portugal, like the majority of European countries, does not offer any institutional support to immigrant minority languages. Maintenance of such languages will only be the result of the community's efforts.

Figure 6 Friends' Nationalities in Portugal

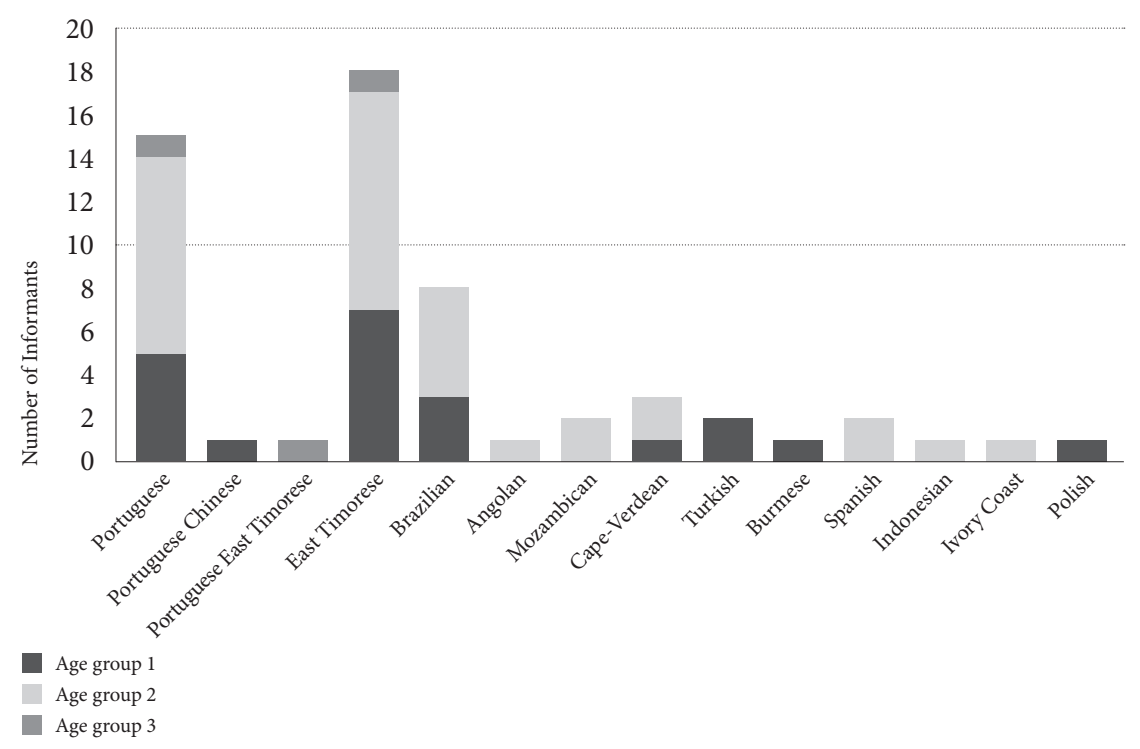

The questionnaires also asked on which occasions the informants meet other East Timorese. The answers include: student halls of residence, the church, the university and specific meetings and events of the East Timorese community. Out of all these only these last two occasions are likely to be ones 
at which East Timorese speak Tetum and the other national languages. Student halls, the university and the church are likely to be Portuguese-dominant. Whereas religious institutions are often regarded as important factors for language maintenance (Fishman, Reversing Language Shift and "Language Maintenance"), Catholic churches in Portugal, where East Timorese immigrants worship, are not committed to the use of community languages.

The survey also reveals that our informants are in contact with the other East Timorese diasporas. Among the most frequently mentioned are: Indonesia (17 answers), England (12), Ireland (7), Australia (13), Philippines (5), Cuba (3), New Zealand (2), USA (3), Brazil (3). This is a good indicator of linguistic and cultural maintenance. The East Timorese diaspora is also directly involved in the on-going language planning in East Timor since many East Timorese are studying or being trained abroad. ${ }^{20}$

Figure 7 Media Used in the Immigration Context

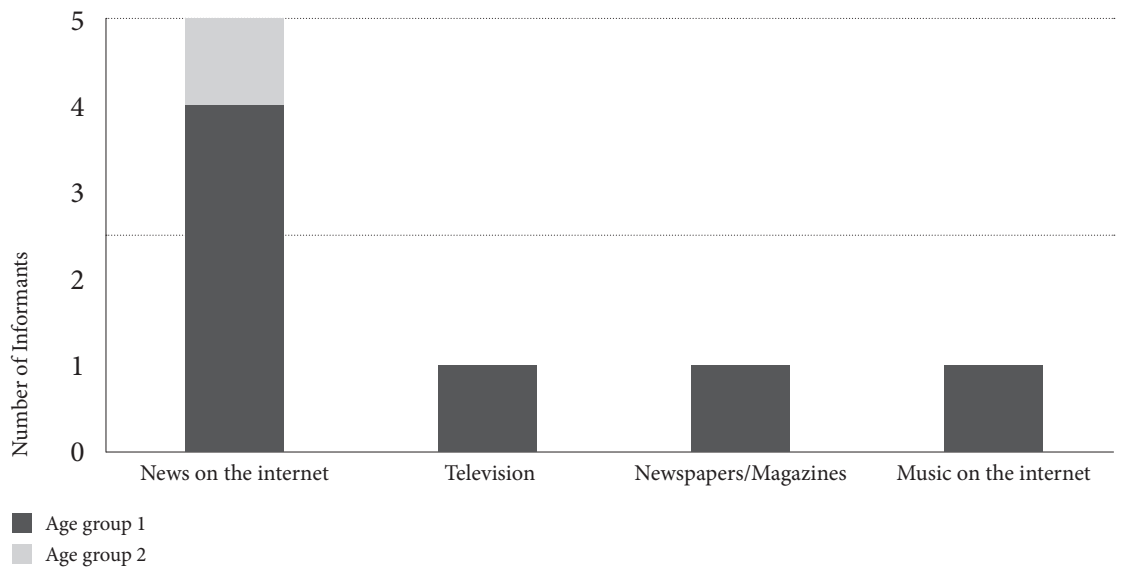

Another important factor for language maintenance is the use of community languages in the media. We asked the informants if they have access to any newspapers, magazines, internet websites or television programs in languages of East Timor other than Portuguese. The overwhelming majority provided a negative answer. Figure 7 summarises the few positive answers. Only one speaker (1X) answers that he reads Bahasa Indonesia "newspapers/ 
magazines and television," possibly accessed in the internet. All the other answers given by the informants mention internet websites: www.tembang. com (Indonesian music), www.timortoday.com and www.cjitl.org/ (news on East Timor). This reinforces the role of Bahasa Indonesia, which is still maintained in the diasporic community. All answers, but one, were given by informants of the youngest age group who constitute a better connected, more open and less tight-knit community.

\section{Conclusions}

This study aimed to examine language choice, language attitudes and language shift among the East Timorese diaspora in Portugal. While East Timorese reproduce their plurilingual repertoire in the immigration context, this repertoire is re-shaped according to three main factors: 1) age group, due to the successive changes in language policy and planning, 2) new language ecology in the host country, and 3) on-going language planning in East Timor.

The results of this study show that both Portuguese and Tetum are maintained, but they are not assigned the same value. The former is perceived as the High language, potentially more useful in both East Timor and Portugal. The latter is regarded as an East Timorese identity marker. While age groups 2 and 3 seem to pass on both Portuguese and Tetum, the youngest generation, age group 1, tends to speak only in Portuguese with their children. This is further evidence of the incipient language shift towards Portuguese, wherein Tetum is used only in domestic domains. There are many factors that may be contributing to this situation of language shift: the level of education of the diaspora, the lack of institutional support for community languages in Portugal, the quest for a better future, and social networks involving other Portuguese-speaking immigrant groups in Portugal.

Surprisingly, our study shows that Bahasa Indonesia is still used in the community in various domains even though it is just a working language in East Timor and not regarded as useful in the immigration context. National languages, which occupy the lowest position in the polyglossic situation in East Timor, occupy an even lower position in the re-shaped linguistic repertoire in the diaspora, where they are abandoned. In some cases, they are the preferred 
languages and hold a symbolic status. Nonetheless, they are not used in any domains or passed on to the next generation in the immigration context where the pan-national East Timorese identity is more important than the ethnic one. Therefore language shift towards Tetum and Portuguese, which is already taking place in East Timor, appears to be accelerated in the immigrant context. Moreover, we observed that speakers do not seem to be aware of differences between European Portuguese and an East Timorese variety, nor of issues of code-switching and mixing between languages of their repertoire, which are typical in such highly multilingual communities.

\section{Notes}

1 We gratefully acknowledge the support of the British Academy (Small Grant SG100616) for the data collection, which took place from June 2010 to March 2011. We thank Khalid Belhajjame, Chloe Paver, Aidan Coveney and Zoe Boughton for comments and suggestions on different drafts of this article.

2 These numbers were contrasted with the numbers provided by Ethnologue (Lewis) and in some cases there is a very large discrepancy. This may be because some of the sources used by Ethnologue are very old.

3 Tetum-Dili has been heavily influenced by Portuguese and Bahasa Indonesia (after 1975).

4 Part VII, Section 159 of the 2002 Constitution states "Indonesian and English shall be working languages within civil service [sic] side by side with official languages as long as deemed necessary".

5 See Hattori et al., van Engelenhoven, DoBeS.

6 In a diglossic situation, the High language is used in formal domains such as administration, education, literature, etc., and is prestigious. In contrast, the Low language is used in informal domains, such as conversations with familiars, friends, etc., and lacks prestige (Fishman, "Bilingualism").

7 All figures are provided by SEF (security service within the Ministry of Home Affairs) and INE (National Institute of Statistics). The official figures from these two organizations differ, hence these are approximate numbers.

8 They were part of the new resistance, which was not Portuguese-speaking, like the original armed resistance, but Bahasa Indonesia-speaking.

9 See Clyne, and Clyne and Kipp

10 The European discourse on minority languages in Europe has focused on Regional Minority Languages rather then the New Immigrant Minorities. The European Charter on Regional and Minority Languages for example does not mention immigrant languages.

11 This is a situation that is common to other Northern European countries. Among others, see studies by Meeuwis on Zairians in Belgium, and Sebba and Wootton on AfricanCaribbean community in England. 
12 As a first language, Portuguese is thriving more in the capital cities, undergoing a process of nativisation.

13 See also Taylor-Leech, "The Ecology of Language Planning" 87.

14 In this and the next figures, the columns are also colour-coded to indicate the age group of the informants.

15 This speaker seems to be more aware of issues of multilingualism and language mixing. He also studied Greek and Latin.

16 This is also the name of an Indonesian dish, which is a mix of raw and cooked vegetables in a spicy peanut sauce.

17 A preliminary analysis of the recorded conversations provides evidence for this. A description of the East Timorese Portuguese is beyond the scope of this article.

18 It is also true that in similar postcolonial contexts, speakers have only recently begun to gain an awareness of a different variety (cf. Indian English, Nigerian English).

19 For example, informant $1 \mathrm{M}$ says "...I socialise more with Timorese friends, but at the university I socialise with Portuguese friends."

20 There are several examples of diasporas which are active in issues of language policy and planning. Among others the Kurdish and the Igbo diasporas which have been involved in issues of standardization of these languages.

\section{Works Cited}

Bolina, Mariette. “Timor e a Língua Portuguesa no seu Projecto Educativo." Revista Lusófona de Educação 6 (2005): 179-193. Print.

Carey, Peter. "Third-World Colonialism, the Geração Foun, and the Birth of a New Nation: Indonesia through East Timorese Eyes, 1975-99." Indonesia 76 (2003): 23-67. Print.

Clyne, Michael. Dynamics of Language Contact. English and Immigrant Languages. Cambridge: Cambridge UP, 2003. Print.

Clyne, Michael, and Sandra Kipp. Pluricentric Languages in an Immigrant Context. Berlin/New York: Mouton de Gruyter, 1999. Print.

Coulmas, Florian. Sociolinguistics: the Study of Speakers' Choices. Cambridge: Cambridge UP, 2005. Print.

Dardjowidjojo, Soenjono. "Strategies for a Successful National Language Policy: The Indonesian Case." International Journal of the Sociology of Language 130 (1998): 35-47. Print.

Direcção Nacional de Estatística (DNE). Censo da População e Habitação (Census of Population and Housing) 2004. Tabelas Prioritárias Nacionais. $1^{\text {st }}$ ed. Dilí: Gráfica Pátria, 2006. Print.

DoBeS (Documentation of Endangered Languages). Documenting Waima'a, East Timor: Language Endangerment and Maintenance in a Newly Emerging Nation. Max-Planck-Institute for Psycholinguistics, n.d. Web. 14 Apr. 2012

Extra, Guus, and Kutlay Yagmur. "Sociolinguistic Perspective on Emerging Multilingualism in Europe." International Journal of the Sociology of Language 175/176 (2005): 17-40. Print.

Fallon, Karla. "Making Noise: The Transnational Politics of Aceh and East Timor in the Diaspora." Diss. The University of British Columbia, Vancouver, 2009. Print. 
Fishman, Joshua. "Bilingualism with or without Diglossia; Diglossia with or without Bilingualism.” Journal of Social Issues 23.2 (1967). 29-38.

_. Reversing Language Shift. Clevedon: Multilingual Matters, 1991. Print.

__. "Language Maintenance, Language Shift, and Reversing." The Handbook of Bilingualism. Ed. Tej K. Bhatia and William C. Ritchie. Oxford: Blackwell Publishing, 2004. 406-436. Print.

Hajek, John. "Language Planning and Sociolinguistic Environment in East Timor: Colonial Practice and Changing Language Ecologies." Current Issues in Language Planning 1.3 (2000): 400-414. Print.

—. "Language Maintenance and Survival in East Timor: All Change Now? Winners and Losers." Ed. David Bradley and Maya Bradley. Language Endangerment and Language Maintenance. London: Routledge, 2002. 182-202. Print.

Hattori, Ryoko, Matias Gomes, Frances Ajo, and Nelson Belo. "The Ethnolinguistic Situation in East Timor." East-West Center Working Papers 20 (2005): 1-18. Print.

Himmelmann, Nikolaus, and John Hajek. "A Report on the Current Sociolinguistic Situation in Laute'm (East Timor)." Studies in Languages and Cultures of East Timor 4 (2001): 88-97. Print.

IEG (Independent Evaluation Group). Timor-Leste Country Program Evaluation, 2000-2010. Washington, DC: Independent Evaluation Group, the World Bank Group, 2011. Print.

Lewis, M. Paul. Ethnologue: Languages of the World. Sixteenth edition. Dallas, Tex.: SIL International, 2009. Web. 14 Apr. 2012.

Malheiros, Jorge M. "Jogos de Relações Internacionais: Repensar a Posição de Portugal no Arquipélago Migratório Global.” Ed. António Barreto. Globalização e Migrações. Lisboa: Imprensa de Ciências Sociais, 2005. 251-271. Print

Märzhäuser, Christina. “Cape Verdean Creole in Lisbon: The Young Generation's Perspective." Ed. Eric A. Anchimbe and Stephen A. Mforteh. Postcolonial Linguistic Voices. Identity Choices and Representations. New York/Berlin: Mouton De Gruyter, 2011. 299-322. Print.

Meeuwis, Michael. Constructing Sociolinguistic Consensus: A Linguistic Ethnography of the Zairian Community in Antwerp, Belgium. Duisburg: LICCA papers, 1997. Print.

Rocha-Trindade, Maria Beatriz. Sociologia das Migrações. Lisboa: Universidade Aberta, 1995. Print.

Sebba, Mark, and Tony Wootton. "We, They and Identity: Sequential Versus Identity-related Explanation in Code-switching." Ed. Peter Auer. Code-switching in Conversation. London: Routledge, 1998. 262-289. Print.

Taylor-Leech, Kerry. "The Ecology of Language Reform in Timor-Leste: A Language Rights Perspective." Studies in Languages and Cultures of East Timor 7 (2005): 1-22. Print.

"The Ecology of Language Planning in Timor-Leste. A Study of Language Policy, Planning and Practices in Identity Construction." Diss. Griffth University, 2007. Print.

“The Language Situation in Timor-Leste." Language Issues in Language Planning 10.1 (2009): 1-68. Print.

van Engelenhoven, Thomas. Fataluku Language Project. Instituto Nacional de Linguística, Timor Lorosa'e. n.d. Web. 14 Apr. 2012

Vale de Almeida, Miguel. An Earth-colored Sea: "Race," Culture", and the Politics of Identity in the Post-colonial Portuguese-speaking World. Oxford: Berghahn Books, 2004. Print. 
Viegas, Telma. Migrações e Associativismo de Migrantes: Estudo de Caso Timorense. Lisboa: Fundação Oriente/Universidade Aberta, 1998. Print.

Wise, Amanda. Exile and Return among the East Timorese. Philadelphia: University of Pennsylvania Press, 2006. Print.

—. "Nation, Transnation, Diaspora: Locating East Timorese Long-distance Nationalism." Sojourn: Social Issues in Southeast Asia 19. 2 (2004): 151-180. Print.

Weatherbee, Donald. "Portuguese Timor: An Indonesian Dilemma." Asian Survey 6.12 (1966): 683-695. Print.

Francesco Goglia is a senior lecturer in Italian at the University of Exeter. His research interests include multilingualism and language contact in immigrant communities, code-switching, and Italian linguistics. He has published on multilingualism among IgboNigerians in Italy, and his current research is on the East Timorese diasporic community in Portugal.

Susana Afonso is lecturer in Hispanic Studies at the University of Exeter. She has published on Portuguese cognitive linguistics and her recent research interests focus on contact between varieties of Portuguese. Her current research is on the East Timorese diasporic community in Portugal. 
